\title{
STRATEGI QUANTUM LEARNING DALAM PENDIDIKAN AKIDAH AKHLAK DI MADARAH IBTIDAIYAH
}

\author{
Mukhlis \\ Dosen STIT Al-Karimiyyah
}

\begin{abstract}
Quantum Learning merupakan pembelajaran yang dapat mengubah suasana belajar yang menyenangkan serta mengubah kemampuan dan bakat alamiah peserta didik menjadi bermanfaat bagi mereka sendiri dan bagi orang lain. Dalam pelaksanaan proses belajar mengajar Guru dituntut untuk menggunakan strategi yang tepat demi tercapai pembelajaran yang efektif. Terdapat beberapa strategi Quantum Learning diantaranya, mendudukkan murid secara nyaman, Memasang musik latar di dalam kelas. Selain itu Guru melaksanakan pembelajaran yang menggunakan alam sebagai tempat untuk mendekatkan siswa dengan peningkatan keimanan, mengajak siswa pada suatu alam baik pegunungan, laut atau tempat-tempat lain yang ada pada lingkungan sekolah untuk mengagumi ciptaan Allah, dan dapat menggunakan berbagai materi, seperti materi bercerita mengenai Nabi dan Malaikat dengan cerita yang menarik dan menyenangkan.
\end{abstract}

Keywords: Quantum Learning, Pendidikan, Akidah Akhlak.

\section{Pendahuluan}

Pembelajaran merupakan proses interaksi peserta didik dengan pendidik dan sumber belajar pada suatu lingkungan belajar. ${ }^{1}$ Dalam pelaksanaan proses belajar mengajar seorang guru tentunya membutuhkan strategi pembelajaran yang

\footnotetext{
${ }^{1}$ Undang-Undang Republik Indonesia Nomor 20 Tahun 2003, Sistem Pendidikan Nasional, (Bandung: Fokus Media, 2006), hlm. 4.
}

Kariman, Volume 06, Nomor 02, Juni 2018 | 183 


\section{Mukhlis}

tepat demi tercapainya proses belajar mengajar yang maksimal. Dalam sistem pembelajaran strategi merupakan sebuah komponen yang sangat berpengaruh dalam dunia pendidikan, terlebih pada proses pembelajaran pendidikan agama Islam. Strategi pembelajaran pendidikan agama Islam ini merupakan salah satu upaya untuk menerapakan bagaimana nilai-nilai ajaran agama Islam yang ada pada tiap materi mampu diserap, dihayati serta bisa diamalkan oleh peserta didik.

Pembelajaran yang berkualitas sangat tergantung pada motivasi para pelajar dan kreatifitas seorang pengajar. Pembelajar yang memiliki motivasi tinggi harus ditunjang dengan pengajar yang mampu memfasilitasi motivasi tersebut, sehingga bisa membawa pada keberhasilan pencapaian target belajar yang baik. Target belajar dapat diukur melalui perubahan sikap dan kemampuan siswa melalui proses belajar. Desain pembelajaran yang baik, tentunya harus ditunjang dengan fasilitas yang memandai, ditambah dengan kreatifitas guru akan membuat peserta didik lebih mudah mencapai target belajar.

Seorang guru dalam melaksanakan proses pembelajaran tentunya memerlukan suasana yang menyenangkan, dialogis dan proses tanya jawab secara terus-menerus untuk meningkatkan kemampuan berfikir siswa yang pada akhirnya mereka dapat mengkonstruksikan pengetahuan sendiri. Dengan suasana yang demikian, maka pembelajaran diharapkan dapat terlaksana dengan hasil yang baik dan menyenangkan. Dengan adanya hal yang demikian, maka penulis tertarik untuk menelusuri dan membahas lebih lanjut tentang Strategi Quantum Learning dalam Pendidikan Akidah Akhlak MI.

\section{Pengertian Strategi Pembelajaran}

Peningkatan layanan pendidikan, khususnya di kelas erat kaintannya dengan usaha guru dalam merancang pembelajaran dan pengembangannya melalui strategi pembelajaran. Secara umum strategi memiliki pengertian suatu garis besar haluan untuk bertindak dalam usaha mencapai sasaran yang telah ditentukan. ${ }^{2}$ Sedangkan pembelajaran, sebagaimana yang didefinisikan Oemar Hamalik adalah suatu kombinasi yang tersusun meliputi unsur-unsur manusiawi, internal material fasilitas, perlengkapan dan prosedur yang saling mempengaruhi untuk mencapai tujuan pembelajaran. ${ }^{3}$

\footnotetext{
${ }^{2}$ Syaiful Bahri Djamarah dan Aswan Zain, Strategi Belajar Mengajar, (Jakarta: Rineka Cipta, 2010), hlm. 5.

${ }^{3}$ Oemar Hamalik, Kurikulum dan Pembelajaran, (Jakarta: PT. Bumi Aksara, 2000), hlm. 57.
} 
Menurut Hamzah B. Uno, strategi pembelajaran adalah cara-cara yang akan digunakan oleh pengajar untuk memilih kegiatan belajar yang akan digunakan selama proses pembelajaran. ${ }^{4}$ Jadi strategi pembelajaran dapat diartikan sebagai perencanaan proses pembelajaran yang sudah didesain untuk mencapai suatu proses belajar mengajar yang lebih berkualitas agar bisa mencapai tujuan pendidikan yang sebenarnya. Strategi pembelajaran ini sangat penting dalam menentukan keberhasilan dalam mencapai tujuan pembelajaran, baik pendidikan umum maupun pendidikan agama Islam.

\section{Sejarah dan Pengertian Quantum Learning}

Bobbi De Porter merupakan tokoh utama dalam pembalajaran Quantum, ia seorang Ibu rumah tangga yang kemudian terjun di bidang bisnis properti dan keuangan, dan setelah semua bisnisnya bangkrut akhirnya menggeluti bidang pembelajaran. Kemudian pada tahun 1982 DePorter mematangkan dan mengembangkan gagasan pembelajaran Quantum di SuperCamp, sebuah lembaga pembelajaran yang membantu ribuan siswa untuk belajar kembali cara mereka menjalani kehidupan mereka. ${ }^{5}$ SuperCamp sendiri didirikan atau dilahirkan oleh Learning Forum, sebuah perusahaan yang memusatkan perhatian pada pembelajaran guna pengembangan potensi diri manusia.

Super Camp, terletak Kirkwood Meadows, Negara Bagian California, Amerika Serikat, DePorter telah membawa SuperCamp keberbagai Negara seperti Moskow, Hong Kong, Singapur, dan Austaralia. Dia belajar dari Dr. Georgi Lozanov, seorang pendidik berkebangsaan Bulgaria yang mempunyai konsep belajar cepat (accelerated learning), dan menerapkan metodenya di sekolah tersebut dengan penuh kesuksesan yang menakjubkan. Dalam menekuni dunia pembelajaran ini, Deporter tidaks sendirian ia dibantu oleh sebuah tim yang solid yang terdiri dari teman-temannya, terutama Eric Jansen, Greg Simmons, Mike Hernacki, Mark Reardon, dan Sarah Singer-Nourine. ${ }^{6}$ Demikianlah sejarah singkat lahirnya pembelajaran Quantum yang dikembangkan pertama kali oleh Bobbi DePorter.

\footnotetext{
${ }^{4}$ Hamzah B. Uno, Model Pembelajaran Menciptakan Proses Belajar Mengajar Yang Kreatif dan Efektif, (Jakarta: Bumi Aksara, 2011), hlm. 3.

${ }^{5}$ Bobbi DePorter \& Mike Hernacki, Quantum Learning; Membiasakan Belajar Nyaman dan Menyenangkan, (Bandung: Kaifa, 2002), hlm. vii

${ }^{6}$ Ngainun Naim, Manjadi Guru Inspiratif; Memberdayakan dan Mengubah Jalan Hidup Siswa, (Yogyakarta: Pustaka Pelajar, 2009), hlm. 201.
} 


\section{Mukhlis}

Pengertian Quantum learning ini sendiri berawal dari upaya Dr.Georgi Lozanov, yang bereksperimen dengan "sugestology" atau "sugestopedia". Prinsipnya bahwa sugesti itu dapat dan pasti mempengaruhi hasil situasi belajar, dan setiap detail apapun itu dapat memberikan sugesti positif atau negatif. Beberapa tektik yang dapat digunakan untuk memberikan sugesti positif adalah dengan menempatkan siswa secara nyaman, memasang musik latar di dalam kelas, meningkatkan partisipasi individu, menggunakan poster-poster besar untuk memberikan kesan besar sambil menonjolkan informasi dan menyediakan pendidik yang terlatih dengan baik dalam seni pengajaran sugestif. ${ }^{7}$ Istilah lain dari suggastology adalah accelerated learning atau "percepatan belajar", yakti adalah accelerated learning atau "percepatan belajar", yakni metode yang memungkinkan siswa untuk belajar dalam kecepatan yang mengesankan dengan upaya yang normal dan diikuti dengan kegembiraan.

Pembelajaran Quantum adalah kiat, petunjuk, strategi dan seluruh proses belajar yang dapat mempertajam pemahaman dan daya ingat, serta membuat belajar sebagai suatu proses yang menyenangkan dan bermanfaat. ${ }^{8}$ Pada prinsipnya dalam pembelajaran Quantum adalah belajar itu harus mengasikkan dan berlangsung dalam suasana yang gembira sehingga pintu masuk untuk informasi baru lebih besar dan terekam dangan baik. ${ }^{9}$ Jadi Quantum Learning atau pembelajaran Quantum dapat dikatakan sebagai pengajaran yang dapat mengubah suasana belajar yang menyenangkan serta mengubah kemampuan dan bakat alamiah siswa menjadi bermanfaat bagi mereka sendiri dan bagi orang lain.

\section{Manfaat dan Tujuan Quantum Learning}

1. Manfaat Quantum Learning

Dalam pembelajaran Quantum memiliki lima manfaat yang akan diuraikan sebagai berikut: ${ }^{10}$

a. Sikap Positif, maksudnya adalah perilaku baik yang sesuai dengan nilai-nilai dan norma-norma kehidupan yang berlaku dalam masyarakat. Dalam pembelajaran sikap positif tentunya dibutuhkan untuk mengantarkan siswa pada sikap yang jujur, bertanggung jawab dengan baik, disiplin dan lain-lain.

\footnotetext{
${ }^{7}$ Ibid, hlm. 14

${ }^{8}$ Haryanto Al-Fandi, Desain Pembelajaran yang Demokratis \& Humanis, (Yogyakarta: Ar-Ruzzmedia, 2011), hlm. 259.

${ }^{9}$ Komaruddin Hidayat, (pengantar), 101 Strategi Pembelajaran Aktif, (Yogyakarta: Yapendis, 2005), hlm. xvi

${ }^{10}$ Bobbi DePorter, Quantum, hlm. 13
}

186 | Kariman, Volume 06, Nomor 01, Juni 2018 
Dengan adanya sikap yang demikian siswa diharapkan dalam mengikuti proses pembelajaran mendapat hasil yang maksimal.

b. Motivasi, dalam pembelajaran motivasi merupakan usaha dari luar dalam hal ini adalah guru untuk mendorong, mengaktifkan dan menggerakkan peserta didiknya secara sadar untuk terlibat secara aktif dalam proses belajar mengajar. Maka bagi guru peranan motivasi ini sangat penting dalam proses belajar mengajar, karena dapat menimbulkan kemauan, memberi semangat, menimbulkan kesadaran untuk meningkatkan prestasi belajarnya. ${ }^{11}$

c. Keterampilan belajar seumur hidup, Keterampilan belajar ditujukan untuk meningkatkan kemampuan seseorang dalam hal belajar, untuk lebih memahami konsep belajar dan untuk menekankan implikasi praktis dari konsep tersebut pada aplikasi nyata dalam kegiatan sehari-hari. Secara khusus keterampilan dalam belajar adalah suatu cara yang dipakai untuk mendapat, mempertahankan, dan mengungkapkan pengetahuan serta untuk mengungkapkan pengetahuan serta merupakan cara untuk menyelesaikan masalah. Untuk memperoleh keterampilan dalam belajar, murid akan menyadari bagaimana cara belajar yang paling baik sehingga lebih bertanggung jawab akan kegiatan belajarnya.

d. Keperyaan diri, Ketika ini dikaitkan dengan pembelajaran, siswa yang memiliki kepercayaan rendah atau telah kehilangan kepercayaan, cenderung merasa bersikap tidak memiliki sesuatu (keinginan, tujuan, target) yang diperjuangkan secara sungguh-sungguh, siswa juga mudah frustasi atau menyerah ketika menghadapi masalah atau kesulitan dalam belajar. Selain itu, hilangnya rasa percaya diri membuat diri siswa kurang termotivasi untuk maju, malas-malasan atau setengah hati dalam proses belajar dan mengembangkan kemampuannya. Akibatnya adalah siswa akan sering gagal dalam menyempurnakan tugas-tugas atau tanggung jawab.

e. Sukses, dalam hal ini sukses merupakan suatu impian atau tujuan yang kita inginkan telah tercapai dengan usaha dan kerja keras yang dijalani dalam hidupnya dalam mencapai kesuksesan dan keinginan tersebut berupa hal yang positif baik untuk diri sendiri dan orang lain, kesuksesan itu tidak hanya berupa materi, tapi kesuksesan itu bisa berupa non materi. Dalam proses pembelajaran guru bisa menjadi penentu kesuksesan dalam keberhasilan murid karena seorang guru bukan sekedar sebagai pemberi

\footnotetext{
${ }^{11}$ Aminuddin Rasyad, Teori Belajar dan Pembelajaran, (Jakarta: Uhamka Press \& Yayasan Pep-ex8, 2006), hlm. 89-90
} Kariman, Volume 06, Nomor 02, Juni 2018|187 
ilmu pengetahuan kepada murid akan tetapi lebih dari itu yaitu sebagai rekan belajar, Fasilitator, dan pengubah kesuksesan siswa. Guru memiliki peranan yang sangat penting untuk mencapai kesuksesan seorang siswanya. ${ }^{12}$

\section{Tujuan Quantum Learning}

Adapun tujuan dari pembelajaran Quantum (Quantum learning) adalah sebagai berikut. ${ }^{13}$

a. Untuk menciptakan lingkungan belajar yang efektif.

b. Untuk menciptakan proses belajar yang menyenangkan.

c. Untuk menyesuaikan kemampuan otak dengan apa yang dibutuhkan oleh otak.

d. Untuk membantu meningkatkan keberhasilan hidup dan karir.

e. Untuk membantu mempercepat dalam pembelajaran.

Tujuan di atas, mengindikasikan bahwa pembelajaran Quantum mengharapkan perubahan dari berbagai bidang mulai dari lingkungan belajar yaitu kelas, materi pembelajaran yang menyenangkan, menyeimbangkan kemampuan otak kiri dan otak kanan, serta mengefisienkan waktu pembelajaran.

\section{Ciri-ciri Quantum Learning}

Dalam pembelajaran Quantum sendiri memiliki cirri-ciri yang secara umum bisa dikatakan mandiri, walaupun tetap tidak bisa dilepaskan sepenuhnya dari pengaruh teori-teori yang lainnya. Beberapa cirri yang membentuk pembelajaran Quantum adalah;

1. Pembelajaran Quantum berpangkal pada psikologi kognitif, dan bukan pada fisika Quantum. Penggunaan istilah quantum tidak mengacu pada konsep fisika quantum, kecuali sebatas analogi beberapa konsep quantum.

2. Pembelajaran Quantum lebih bersifat humanistis, bukan positivistis empiris, atau nativistis. Dalam perspektif semacam ini, posisi manusia sebagai pembelajar menjadi pusat perhatiannya. Potensi diri, kemampuan pikiran, daya motivasi, dan sebagainya dari pembelajar diyakini dapat berkembang secara maksimal.

\footnotetext{
${ }^{12}$ Rokhman, Desain Pembelajaran Pendidikan Agama Islam; Konsep,Prinsip, dan Aplikasi (Yogyakarta: Idea Press Yoykarta, 2009), hlm. 86

${ }^{13}$ DePorter, Quantum, hlm. 12.
}

188 | Kariman, Volume 06, Nomor 01, Juni 2018 
Hal inilah nampaknya kurang memperoleh apresiasi dari konsep pembelajaran yang selama ini kita praktikkan.

3. Pembelajaran Quantum memusatkan perhatian pada intraksi yang bermutu dan bermakna, bukan sekedar transaksi makna. Oleh karena itu, pembelajaran dipandang sebagai penciptaan interaksi-interaksi bermutu dan bermakna yang dapat mengubah energi kemampuan pikiran dan bakat alamiah pembelajar menjadi cahaya-cahaya yang bermanfaat bagi keberhasilan pembelajar. Interakasi yang tidak mampu mengubah energy menjadi cahaya harus dihindari, kalau perlu dibuang jauh dalam proses pembelajaran.

4. Pembelajaran Quantum sangat menekankan pada pemercepatan pembelajaran dengan taraf keberhasilan tinggi. Di sini, pemercepatan pembelajaran diandaikan sebagai lompatan quantum, di mana segala hambatan dan halangan yang dapat melambatkan proses pembelajaran harus disingkirkan. Dalam usaha pemercepatan ini, berbagai teknik dapat dipergunakan untuk mencapai hasil pembelajaran yang lebih maksimal.

5. Pembelajaran Quantum memiliki model yang memadukan konteks dan isi pembelajaran. Konteks pembelajaran meliputi suasana yang memberdayakan, landasan yang kukuh, lingkungan yang menggairahkan atau mendukung, dan rancangan belajar yang dinamis.

6. Pembelajaran Quantum memusatkan perhatian pada pembentukan keterampilan akademis, keterampilan hidup, dan prestasi fisikal atau material. Ketiganya harus diperhatikan, diperlukan, dan dikemlola secara seimbang dan relatif sama dalam dalam proses pembalajaran; tidak bisa hanya salah satu di antaranya. Hal ini disebabkan karena pembelajaran yang berhasil bukan diindikasikan oleh terbentuknya keterampilan akademis dan prestasi fisikal pembelajaran, namun lebih penting lagi bagaimana terbentuknya keterampilan hidup pembelajar.

7. Pembelajaran Quantum menempatkan nilai dan keyakinan sebagai bagian penting dalam proses pembelajaran. Tanpa nilai dan keyakinan tertentu, proses pembelajaran kurang bermakna. Untuk itu, pembelajaran harus memiliki nilai dan keyakinan tertentu yang positif dalam proses pembelajaran. Di samping itu, proses pembelajaran hendaknya menanamkan nilai dan keyakinan positif dalam diri pembelajar. Nilai dan keyakinan negatif akan membuahkan kegagalan proses pembelajaran. 


\section{Mukhlis}

8. Pembelajaran Quantum mengintegrasikan totalitas tubuh dan pikiran dalam proses pembelajaran. Aktivitas total antara tubuh dan pikiran membuat pembelajaran bisa berlangsung lebih nyaman dan hasilnya lebih optimal. ${ }^{14}$

Ciri-ciri pembelajaran quantum yang telah disebutkan diatas tentunya diharapkan bisa menjadi motivasi pada guru, agar dalam proses belajar mengajar dapat melaksanakan dengan cara yang baik. Hal tersebut tentunya juga penting untuk diketahui oleh setiap pendidk sehingga dalam proses pembelajaran mengsilkan dengan hasil yang sesuai dengan harapan semua peserta didik. Selain itu, seorang guru diharapkan bisa memadukan potensi yang terdapat pada diri siswa untuk dikembangkan kearah yang lebih baik lagi.

\section{Strategi Quantum Learning}

Di dalam proses belajar mengajar, guru harus memiliki strategi, agar siswa dapat belajar secara efektif dan efisien, mengenai tujuan yang diharapkan. Salah satu langkah untuk memiliki strategi itu ialah harus menguasai teknik-teknik penyajian, atau biasanya disebut metode mengajar. ${ }^{15}$ Dengan memahami teknik-teknik dalam pembelajaran tentunya guru bisa melaksanakan pembelajaran dengan hasil yang baik. Hal ini menjadi harapan semua peserta didik agar guru sebagai pendidik dituntut untuk tetap memberikan sistem pembelajaran yang menarik dan menyenangkan.

Dalam hal ini akan dijelaskan tentang Strategi Quantum learning di antaranya adalah sebagai berikut ${ }^{16}$ :

1. Mendudukkan murid secara nyaman.

2. Memasang musik latar di dalam kelas.

3. Menggunakan poster-poster untuk memberi kesan besar sambil menonjolkan informasi.

4. Menyediakan guru-guru yang terlatih baik dalam seni pengajaran.

Strategi pembelajaran Quantum yang telah disebutkan setidaknya bisa memberikan pengetahuan yang baru bagi semua pendidik. Sebab bagaimanapun juga dalam proses belajar mengajar tentunya membutuhkan strategi yang tepat, dan berkualitas untuk menjadikan pembelajaran yang lebih berkualitas. Selain itu,

\footnotetext{
${ }^{14}$ Ngainun Naim, Manjadi Guru Inspiratif, hlm. 205-210.

${ }^{15}$ Roustiyah N.K, Strategi Belajar Mengajar,(Jakarta: Rineka Cipta, 2008), hlm. 1

16 Yatim Riyanto, Paradigma Baru Pembelajaran; Sebagai Referensi dari Bagi Pendidik dalam Iplementasi Pembelajaran yang Efektif dan Berkualitas, (Jakarta: Kencana, 2010), 184.
} 
Mukhlis

guru juga harus bisa menerapkan strategi pembelajaran yang sudah ada, agar dalam pelaksanaan pembelajaran siswa dapat menerima dangan nyaman dan suasanya kelas yang menyanangkan. Oleh Karena itu, strategi dalam pembelajaran merupakan komponen dalam sistem pendidikan yang dapat menciptakan aktifitas pendidikan menjadi lebih efektif dan efesien.

Selain itu juga ada beberapa strategi pembelajaran Quantum lain yang dikemukan oleh Deporter di antaranya ${ }^{17}$ :

a. Teori otak kanan atau kiri. Dalam hal ini otak kanan dan otak kiri memiliki fungsi yang berbeda-beda. Proses berfikirnya otak kiri bersifat logis, sekuensial, linear, dan rasional. Cara berpikrnya sesuai untuk tugas-tugas teratur ekspresi verbal, menulis, membaca, asosiasi auditorial, menempatkan detail dan fakta, fonetik, serta simbolisme. Sedangkan otak kanan cara berpikirnya bersifat acak, tidak teratur, intuitif, dan holistik. Cara berpikirnya sesuai dengan cara-cara untuk mengetahui yang yang bersifat nonverbal, seperti perasaan dan emosi, kesadaran yang berkenaan dengan perasaan (merasakan kehadiran suatu benda benda atau orang), kesadaran spasial, pengenalan bentuk dan pola, musik, seni, kepekaan warna, kreavitas dan visualisasi.

b. Pilihan modalitas (visual, auditorial, dan kinestik). Visual digunakan untuk mengakses citra visual, warna, gambar, catatan, tabel diagram, grafik, serta peta pikiran, dan hal-hal lain yang terkait. Auditorial, modalitas ini mengakses segala macam bunyi, suara, musik, nada, cerita, irama, dialog, dan pemahaman materi pelajaran dengan menjawab atau mendengarkan lagu, syair dan lain-lain. Kinestetik untuk mengakses segala jenis gerak, aktifitas tubuh, emosi, koordinasi dan hal-hal lain yang terkait.

c. Teori kecerdasan ganda. Salah satu karakteristik penting dari individu yang perlu difahami oleh guru sebagai pendidik adalah bakat dan kecerdasan individu. Guru yang tidak memahami kecerdasan anak didik akan memiliki kesulitan dalam memfasilitasi proses pengembangan potensi individu menjadi yang dicita-citakan. Teori Kecerdasan Ganda (Multiple Inteligence) yang dikemukakan oleh Howard Gardner seorang professor psikologi dari Harvard University agar dapat dijadikan acuan oleh guru untuk lebih memahami bakat dan kecerdasan individu.

d. Pendidikan holistik. Pendidikan holistik merupakan suatu filsafat pendidikan yang berangkat dari pemikiran bahwa pada dasarnya seorang individu dapat

\footnotetext{
${ }^{17}$ Bobbi Deporter, Quantum, hlm. 16- 28
}

Kariman, Volume 06, Nomor 02, Juni 2018|191 


\section{Mukhlis}

menemukan identitas, makna dan tujuan hidup melalui hubungannya dengan masyarakat, lingkungan alam, dan nilai-nilai spiritual. Tujuan pendidkan holistik adalah membantu mengembangkan potensi individu dalam suasana pembelajaran yang lebih menyenangkan dan menggairahkan, demokratis dan humanis melalui pengalaman dalam berinteraksi dangan lingkungannya. Melalui pendidikan holistik, peserta didik diharapkan dapat menjadi dirinya sendiri (learning to be). Dalam arti dapat memperoleh kebebasan psikologis, mengambil keputusan yang baik, belajar melalui cara yang sesuai dengan dirinya, memperoleh kecakapan sosial, serta dapat mengembangkan karakter dan emosionalnya.

e. Belajar berdasarkan pengalaman. Belajar melalui pengalaman merupakan proses belajar dan proses perubahan yang menggunakan pengalaman sebagai media belajar atau pembelajaran. Apa-apa yang dialami secara aktif dan diusahakan untuk proses pemahaman, mencari makna daripada pengalaman tersebut ialah pembelajaran melalui pengalaman. Di dalam kelas, guru dalam merancang pelajaran harus melibatkan anak-anak melalui pengalaman. Selain itu juga, guru dalam mempraktekkan pembelajaran melibatkan banyak teori, tetapi adalah dari sudut praktikal, yaitu melalui pengalaman sendiri.

f. Belajar dengan Simbol. Dalam proses pembelajaran simbol merupakan salah satu hal yang terpenting dalam kegiatan belajar mengajar. Sebagai seorang guru hendaknya bisa menggunakan simbol-simbol yang ada kaitannya dengan proses pembelajaran. simbol-simbol dalam pembelajaran yang sifatnya teoritis hendaknya dapat di wujudnya dalam bentuk kegiatan yang nyata dengan memanfaatkan fasilitas yang ada di lingkungan sekitar. Hal ini tentunya bertujuan agar dalam proses pembelajaran lebih bermakna, dan bermanfaat bagi siswa sendiri maupun orang lain.

g. Simulasi. Metode simulasi salah satu metode mengajar yang dapat digunakan dalam pembelajaran kelompok. Proses pembelajaran yang menggunakan metode simulasi cendrung objeknya bukan benda atau kegiatan yang sebenarnya, melainkan kegiatan mengajar yang sifatnya berpura-pura. Gladi resik merupakan salah satu contoh simulasi, yakni memperagakan proses terjadinya suatu acara tertentu sebagai latihan untuk upacara sebenarnya supaya tidak gagal dalam waktunya nanti. Jadi metode simulasi adalah peniruan atau perbuatan yang bersifat menirukan suatu peristiwa seolah-olah seperti peristiwa yang sebenarnya. 
Faktor-faktor yang mempengaruhi keberhasilan penerapan strategi

1. Kamampuan guru

2. Keaktifan siswa dan partisipasinya

3. Sarana belajar dan lingkungan belajar ${ }^{18}$

Ketiga faktor diatas tentunya harus saling berkaitan antara yang satu dangan faktor yang lainnya. Sebab hal tersebut tidak bisa dipisahkan sehingga perlu adanya hubungan yang bisa mengantarkan proses pembelajaran yang lebih baik. Oleh karena itu, keberhasilan penerapan strategi pembelajaran memang tidak bisa dipisahkan dari kemampuan guru dalam mengelola proses belajar mengajar. Selain itu juga, tidak kalah pentingnya sarana dan prasarana yang ada dalam sekolah tentunya juga sangat berpengaruh terhadap keberhasilan tercapai proses pembelajaran yang baik. Untuk itu, diperlukan strategi yang tepat guna bisa mencapai pembelajaran yang dingikan oleh setiap para peserta didik.

\section{Peran Guru dalam Penerapan Strategi}

a. Mengemukakan berbagai kemungkinan tujuan pembelajaran yang harus dicapai sebelum kegiatan pembelajaran dimulai.

b. Menyusun tugas-tugas belajar bersama siswa.

c. Memberikan informasi tentang kegiatan pembelajaran yang harus dilakukan.

d. Memberikan bantuan dan pelayanan kepada siswa yang memerlukannya.

e. Memberikan motivasi, membimbing, mendorong siswa untuk belajar.

f. Membantu siswa dalam menarik kesimpulan. ${ }^{19}$

\section{Strategi Pendidikan Akidah Akhlak MI}

Berkenaan dengan strategi, dalam bahasa Arab dikenal istilah thariqah" yang berarti" jalan yang dilalui, istilah lainnya adalah manhaj" yang berarti "syaitan". ${ }^{20}$ Thariq" mengandung arti yang sama dengan yaitu jalan yang ditempuh sebagai saran untuk mengantarkan kepada tujuan. Sehubungan dengan metode ini dalam ajaran Islam dikenal juga beberapa metode, yang antara lain adalah:

\footnotetext{
${ }^{18}$ Umi Uripah, Pembelajaran Pendidikan Agama Islam; Strategi dan Metodologi, (Yogyakarta: Idea Press, 2012), hlm. 139.

${ }^{19}$ Mahmud Arif, Materi Kuliah Pembelajaran PAI Strategi dan Metodologi, Tentang Strategi Pembelajaran Berorientasi Aktifitas dan Partisipasi Siswa.

${ }^{20}$ Ahad Sakka, Strategi Pembelajaran Pendidikan Agama Islam di Sekolah; Teori, Metodologi dan Implementasi, (Yogyakarta: Idea Press, 2012), hlm. 312.
}

Kariman, Volume 06, Nomor 02, Juni 2018|193 


\section{Mukhlis}

1. Metode Teladan. Metode ini dicantumkan dalam al-Qur'an yang menggambarkan keteladanan para Rasul dan umat lainnya. Keteladanan yang baik atau uswatun hasanah merupakan salah satu metode yang sangat dianjurkan dalam mengajarkan agama Islam.

2. Metode Nasehat. Metode ini digambarkan dalam berbagai ayat al-Qur'an yang biasanya dimulai dengan keteladanan dari sipemberi nasehat. Hal ini penting untuk tetap dilakukan oleh setiap pendidik agar para peserta didik dapat melaksanakan dengan baik apa yang sudah diperintahkan oleh seorang guru.

3. Metode Pembiasaan. Metode ini pada dasarnya adalah membiasakan perbuatan-perbuatan baik seperti jujur, dermawan, suka menolong, berserah diri, taat. Hal-hal tersebut merupakan fenomina yang sering ada dalam kehidupan manusia sehari-hari. Tentunya hal ini perlu untuk tetap dikembangkan oleh setiap manusia agar dalam menjalankan kehidupan dapat berjalan dengan baik. ${ }^{21}$

\section{Strategi Quantum learning dalam Pendidikan Akidah Akhlak MI}

Dalam pembelajaran Pendidikan Akidah Akhlak MI, penguasaan guru akan materi dan pemahaman dalam memilih strategi yang tepat akan sangat menentukan keberhasilan pencapaian tujuan pembelajaran. Salah satu strategi tersebut, adalah melalui strategi Quantum learning. Maka dari itu, ada beberapa strategi yang sebaiknya dilakukan oleh guru agar siswa dapat lebih nyaman dan menyenangkan dalam pembelajaran. Untuk itu, strategi qunatum learning dalam Pendidikan Akidah Akhlak MI diantaranya adalah. ${ }^{22}$

1. Guru Pendidikan Akidah akhlak hendaknya banyak melaksanakan pembelajaran yang menggunakan alam sebagai tempat untuk mendekatkan siswa dengan peningkatan keimanan, sebagai contoh pada materi iman kepada Allah.

2. Seorang guru hendaknya mengajak siswa pada suatu alam baik pegunungan, laut atau tempat-tempat lain yang ada pada lingkungan sekolah untuk mengagumi ciptaan Allah.

3. Guru dalam Pendidikan Akidah Akhlak MI yang menggunakan quantum learning dapat menggunakan berbagai materi, seperti materi bercerita mengenai Nabi dan Malaikat dengan cerita yang menarik dan menyenangkan.

\footnotetext{
${ }^{21}$ Ahad Sakka, Strategi Pembelajaran, hlm. 312-313.

${ }^{22}$ Rokhman, Desain Pembelajaran, hlm. 93.
} 
Dengan adanya strategi tersebut tentunya para siswa tidak akan merasa bosan jika belajar di alam terbuka, dapat dibayangkan ketika siswa terus-menerus di dalam kelas mendenger instruksi guru untuk selalu taat dan melaksanakan ajaran-ajaran agama yang terkesan agak kaku di ruang kelas terus-menerus. Dalam pendidikan Akidah Akhlak prinsip-prinsip untuk selalu meningkatkan keimanan dan ketaqwaan pada Allah selalu menjadi prioritas, karena apabila peserta didik telah memiliki keimanan yang tinggi akan mempengaruhi perilaku pada dirinya dan akan berpengaruh pada kepribadian muslim yang baik yang akan selalu senang dan optimis dengan usaha belajarnya. ${ }^{23}$

\section{Kesimpulan}

Pembelajaran quantum pertama kali dicetuskan oleh Bobbi Deporter dan kemudian mendirikan lembaga SuperCamp. Pembelajaran quantum merupakan kiat, petunjuk, strategi dan seluruh proses belajar yang dapat mempertajam pemahaman dan daya ingat, serta membuat belajar sebagai suatu proses yang menyenangkan dan bermanfaat. Dalam perkembangannya pembelajaran quantum memiliki tujuan dan manfaat pada setiap proses pembelajaran. tujuan dari pembelajaran quantum salah satunya adalah untuk menciptakan lingkungan belajar yang efektif. Sedangkan manfaat dari pembelajaran quantum, dapat menjadikan sikap positif, motivasi, sukses, percaya diri dan keterampilan belajar.

Dalam pelaksanaan proses belajar mengajar tentunya membutuhkan strategi yang tepat demi tercapai pembelajaran yang efektif. Dalam pembelajaran quantum terdapat beberapa strategi pembelajaran diantaranya, mendudukkan murid secara nyaman, Memasang musik latar di dalam kelas dan lain sebagainya. Dalam hal ini juga pembelajaran quantum memiliki ciri-ciri pembelajaran yang mungkin beda dari pembelajaran yang lain. Misalnya, Pembelajaran Quantum menempatkan nilai dan keyakinan sebagai bagian penting dalam proses pembelajaran. Selain itu, Strategi Quantum Learning Pendidikan Akidah akhlak MI, Guru hendaknya banyak melaksanakan pembelajaran yang menggunakan alam sebagai tempat untuk mendekatkan siswa dengan peningkatan keimanan, mengajak siswa pada suatu alam baik pegunungan, laut atau tempat-tempat lain yang ada pada lingkungan sekolah untuk mengagumi ciptaan Allah, dan dapat menggunakan berbagai materi, seperti materi bercerita mengenai Nabi dan Malaikat dengan cerita yang menarik dan menyenangkan.

${ }^{23} \mathrm{Ibid}$

Kariman, Volume 06, Nomor 02, Juni 2018| 195 


\section{DAFTAR PUSTAKA}

Al-Fandi, Haryanto, Desain Pembelajaran yang Demokratis \& Humanis, Yogyakarta: Ar-Ruzzmedia, 2011.

Aswan Zain, Syaiful Bahri Djamarah , Strategi Belajar Mengajar, Jakarta: Rineka Cipta, 2010.

Arif, Mahmud, Materi Kuliah Pembelajaran PAI Strategi dan Metodologi, Tentang Strategi Pembelajaran Berorientasi Aktifitas dan Partisipasi Siswa.

B. Uno, Hamzah, Model Pembelajaran Menciptakan Proses Belajar Mengajar Yang Kreatif dan Efektif, Jakarta: Bumi Aksara, 2011.

Deporter, Bobbi dkk, Quantum Teaching; Mempraktikkan Quantum Learning di Ruang-Ruang Kelas,Terj Ary Nilandari, Bandung: Kaifa, 2007.

Deporter, Bobbi \& Hernacki, Mike, Quantum Learning; Membiasakan Belajar Nyaman dan Menyenangkan, Bandung: Kaifa, 2002.

Hidayat, Komaruddin, (pengantar), 101 Strategi Pembelajaran Aktif, Yogyakarta: Yapendis, 2005.

Hamalik, Oemar, Kurikulum dan Pembelajaran, Jakarta: PT. Bumi Aksara, 2000.

Naim, Ngainun, Manjadi Guru Inspiratif; Memberdayakan dan Mengubah Jalan Hidup Siswa, Yogyakarta: Pustaka Pelajar, 2009.

Rasyad, Aminuddin, Teori Belajar dan Pembelajaran, Jakarta: Uhamka Press \& Yayasan Pep-ex8, 2006.

Rokhman, Desain Pembelajaran Pendidikan Agama Islam; Konsep,Prinsip, dan Aplikasi ,Yogyakarta: Idea Press Yoykarta, 2009.

Roustiyah N.K, Strategi Belajar Mengajar ,Jakarta: Rineka Cipta, 2008. 
Riyanto, Yatim, Paradigma Baru Pembelajaran; Sebagai Referensi dari Bagi Pendidik dalam Iplementasi Pembelajaran yang Efektif dan Berkualitas, Jakarta: Kencana, 2010.

Sakka, Ahad, Strategi Pembelajaran Pendidikan Agama Islam di Sekolah ; Teori, Metodologi dan Implementasi, Yogyakarta: Idea Press, 2012.

Undang-Undang Republik Indonesia Nomor 20 Tahun 2003, Sistem Pendidikan Nasional, Bandung: Fokus Media, 2006.

Uripa, Umi, Pembelajaran Pendidikan Agama Islam; Strategi dan Metodologi, Yogyakarta: Idea Press, 2012. 
Mukhlis

198 | Kariman, Volume 06, Nomor 01, Juni 2018 